\title{
ТЕОРЕТИЧНІ АСПЕКТИ ПРОФЕСІЙНОЇ КОМПЕТЕНТНОСТІ ВЧИТЕЛЯ ОБРАЗОТВОРЧОГО МИСТЕЦТВА
}

\author{
Фурсикова Т. В. Теоретичні аспекти професійної компетентності вчителя \\ образотворчого мистеитва. \\ У статті проаналізовано поняття, зміст та елементи професійної компетентності \\ вчителя образотворчого мистецтва. \\ Ключові слова: образотворче мистецтво, учитель, професійна компетентність. \\ Фурсикова Т. В. Теоретические аспекты профессиональной компетентности учителя \\ изобразительного искусства. \\ В статье проанализированы понятие, содержание $и$ элементы профессиональной \\ компетентности учителя изобразительного искусства. \\ Ключевые слова: изобразительное искусство, учитель, профессиональная компетентность. \\ Fursikova T. Theoretical aspects of professional competence of teachers of fine arts. \\ The article analyzes the concept, contents and elements of professional competence of teachers of fine arts. \\ Key words: fine art, teacher, professional competence.
}

Постановка проблеми. Концепція художньо-естетичного виховання учнів у загальноосвітніх навчальних закладах та Комплексна програма художньо-естетичного виховання в загальноосвітніх та позашкільних навчальних закладах вимагає певних змін у художній освіті відповідно до умов сьогодення. Ці зміни повинні сприяти особистісному розвитку школярів, що передбачає виховання в них системи цінностей, збагачення емоційно-почуттєвої сфери, стимулювання образно-асоціативного мислення, розвиток творчого потенціалу на основі виявлення індивідуальних здібностей, різнобічних естетичних потреб та інтересів.

Такі завдання окреслюються також у творчій спадщині В. Сухомлинського, який, роздумуючи над педагогічною працею та порівнюючи іiі з роботою майстра-ювеліра, у статті «Людина неповторна» вказує на способи вивчення та виховання особистості школяра, а саме: «розпізнати, виявити, розкрити, виростити, виплекати в кожного учня його неповторно індивідуальний талант» $[1$, с. 96]. Проблему розкриття індивідуальних (творчих) здібностей кожного учня педагог вважав важливим педагогічним завданням, оскільки «учительська професія - це людинознавство, постійне проникнення в складний духовний світ людини, яке ніколи не припиняється». Одним із найважливіших інструментів упливу педагога на духовний світ школяра, на думку В. Сухомлинського, є «слово вчителя, краса довкілля й мистецтва» [1, с. 420-425].

Успішне розв'язання окреслених завдань у контексті Болонського процесу передбачає переорієнтованість вищої освіти на підготовку вчителя образотворчого мистецтва, який має не тільки базові знання і практичні вміння, але й характеризується високим рівнем готовності до виконання професійних обов'язків, рівнем власної підготовленості [2]. 
Аналіз актуальних досліджень. Питання професійної компетентності вчителя постійно перебувають у центрі уваги значної кількості науковопедагогічних досліджень. Вагомий внесок у розв'язання цього завдання зробили науковці: Н. Бібік, В. Кравцов, О. Овчарук, О. Пометун, О. Савченко, О. Хуторський та інші. Цей факт є визнанням того, що професійна компетентність відіграє провідну роль у діяльності вчителя, що зумовлює вивчення змісту цього феномену.

Метою статті $\epsilon$ розкриття змістового наповнення поняття «професійна компетентність вчителя образотворчого мистецтва».

Виклад основного матеріалу. На основі аналізу літературних джерел ми підтвердили, що науковці мають різні позиції до визначення змісту поняття «компетентність». Нині наявна досить усталена позиція, відповідно до якої досліджуване поняття передбачає знання, уміння, навички здійснення педагогічної діяльності (Н. Тализіна, А. Щербаков та інші). Л. Мітіна в структурі професійної компетентності вчителя виокремлює підструктури (знання, уміння, навички і способи здійснення педагогічної діяльності і знання, уміння, навички і способи здійснення педагогічного спілкування). Аналіз літератури з проблеми дослідження свідчить про те, що переважно наявна спроба наповнити зміст професійної компетентності лише визначеними знаннями, уміннями, навичками та досвідом учителя. Так, П. Симонов під компетентністю розуміє не просте володіння знаннями, а потенційну готовність розв'язувати задачі зі знанням справи [3, с. 62].

На думку М. Чошанова, компетентність як специфічна якість сукупності професійних знань і умінь виражається в таких аспектах:

1. Знання компетентної людини оперативні і мобільні, вони постійно оновлюються.

2. Компетентність містить як змістовий (знання), так і процесуальний (уміння) компоненти. Необхідно не тільки знати суть проблеми, але й уміти вирішувати її практично, причому оптимальним способом, тобто гнучкість методу - обов'язкова характеристика компетентності.

3. Компетентність передбачає уміння обирати оптимальні рішення, аргументувати вибір, відкидати помилкові шляхи, тобто мати критичність мислення.

Отже, на думку М. Чошанова, зміст поняття «компетентність» містить такі основні ознаки: мобільність знань, гнучкість методу і критичність мислення [4, с. 26].

В. Слободчиков під педагогічною компетентністю загалом розуміє здатність побудови систем освітніх (розвиваючих) ситуацій у межах визначеного вікового інтервалу (освітнього рівня) [5, с. 23].

Т. Базаров виокремлюе три види компетентності вчителя: методичну, професійну і соціальну. На його думку, успішність діяльності вчителя залежить від однаковою мірою високої компетентності у всіх сферах [6, с. 13].

Зміст професійної компетентності майбутніх учителів образотворчого мистецтва аналізується нами в контексті навчально-виховного процесу ВНЗ. 
Наше дослідження пов'язане з професійно-педагогічною діяльністю майбутнього учителя образотворчого мистецтва, тому вважаємо за потрібне визначити сутність і структуру професійної діяльності майбутніх учителів.

Ми розглядаємо професійну діяльність учителів образотворчого мистецтва у двох аспектах: як педагогічну та художню. У філософському словнику художня діяльність визначається як «діяльність, у процесі якої створюється і сприймається твір мистецтва. Художня діяльність містить різні види людської діяльності (перетворювальну, пізнавальну, оцінну, виховну, комунікативну, ігрову), які входять до художньої діяльності завдяки притаманному їм художньому аспекту. Найголовніша ланка художньої діяльності - твір мистецтва. У мистецтві здійснюється художнє пізнання і художня оцінка світу, створюється нова художня реальність» [7, с. 590]. Як бачимо, філософське розуміння художньої діяльності досить багатогранне.

У контексті нашого дослідження під художньою діяльністю вчителя образотворчого мистецтва слід розуміти педагогічну діяльність, яка організована для створення і сприйняття творів мистецтва. Належна увага в цьому визначенні звертається на творче сприйняття: «Сприйняття, освоєння творів мистецтва як носіїв художньої цінності - теж діяльність, яка деякою мірою подібна до їх творчого створення. Без особистої активності, без творчої уяви, без співучасті, співпереживання людини, яка сприймає мистецтво, без іï образного мислення картина, наприклад, так і залишиться шматком полотна з нанесеними фарбами» [7, с. 531].

У словнику-довіднику з образотворчого мистецтва художня діяльність трактується не через іiі складники, а за допомогою художнього образу. «Художня діяльність - найзагальніше поняття на означення творчої активності людини (як розумової, інтелектуальної, так і матеріально-практичної), спрямоване на створення художніх образів у будь-якій формі. Художня діяльність - частина культури, спосіб художньої діяльності - мистецтво» [8, с. 203].

Узагальнюючи обидва підходи, зазначимо, що вони віддзеркалюють розуміння художньої діяльності в широкому смислі як «загалом заняття мистецтвом на відміну від наукової діяльності» [9, с. 11-19].

Художню діяльність ми розглядаємо у більш вузькому сенсі - як образотворчу діяльність, що передбачає створення зображень на площині та в просторі, а також сприйняття творів образотворчого мистецтва.

Розглядаючи художню діяльність як складник професійної діяльності вчителя образотворчого мистецтва, уважаємо за потрібне конкретизувати це явище в контексті структури педагогічної діяльності. Зауважимо, що одні дослідники в змісті педагогічної діяльності виокремлюють сукупність професійних знань і вмінь, оволодіння якими забезпечить результативність учительської праці; інші - співвідносять сутність педагогічної діяльності із професійно-особистісними якостями вчителя, від наявності яких залежить успіх його діяльності. Такі підходи є однобічними, оскільки професійна діяльність вчителя поєднує в собі і набуті професійно-педагогічні знання, вміння й навички, і комплекс особистісних якостей. Педагогічна діяльність - 
цілісне явище. Трактування професійної діяльності вчителя лише з функціональних позицій не підтримував В. Сластьонін, оскільки був переконаний, що «педагогічна діяльність розглядається як цілісний об'єкт дослідження» [10, с. 379]. Структуру педагогічної діяльності, на думку В. Сластьоніна, можна подати як єдність мети, мотивів, дій (операцій), результату.

У контексті професійної діяльності вчителя образотворчого мистецтва зазначена структура 3 урахуванням художнього складника може бути пояснена системоутворювальною характеристикою діяльності, у тому числі i педагогічної. Мета педагогічної діяльності вчителя образотворчого мистецтва пов'язана 3 реалізацією мети художньо-естетичного виховання. Мета образотворчої діяльності - створення зображення. За визначенням В. Власова, «зображення - спосіб матеріалізації зорового образу навколишньої дійсності, сам процес такої матеріалізації, що передбачає використання певних засобів технічних прийомів і матеріалів, а також кінцевий результат цього процесу, тобто власне матеріальна форма зорового, а в мистецтві художнього образу» $[11$, c. 82]. Наведене визначення об'єднує усі етапи образотворчої діяльності, що потрібно враховувати в процесі формулювання завдань художньопедагогічної діяльності. В одному випадку постає завдання матеріалізації зорового образу; в другому - метою образотворчої діяльності, зображення, стане процес матеріалізації зорового образу, тобто завдання буде конкретизуватися навколо вибору форми образу; в третьому - метою образотворчої діяльності може стати ії оцінка, тобто з'ясування, наскільки відтворює результат початковий задум, ідею. Завершена робота має ще одну особливість - матеріалізувавшись, зображення починає існувати самостійно $\mathrm{i}$ потребує нового виду образотворчої діяльності - сприйняття зображення.

Отже, професійна діяльність учителя образотворчого мистецтва передбачає інтеграцію образотворчої діяльності, тобто вміння створювати зображення й естетично сприймати їх, i педагогічної діяльності, тобто озброєння учнів способами і прийомами створення зображення і розвиток у них здатності естетично сприймати ці зображення.

На основі аналізу психолого-педагогічних джерел і досліджень у царині образотворчого мистецтва (С. Коновець, Б. Неменський, М. Ростовцев та інші) наведемо порівняльну характеристику образотворчої та педагогічної діяльності. Творчий характер педагогічної діяльності $\epsilon$ найважливішою особливістю, проте на відміну від творчості в образотворчого мистецтва, творчість учителя не має на меті створення соціально цінного нового, оригінального, оскільки його продуктом завжди залишається розвиток особистості. В образотворчій діяльності все сприймається опосередковано через виражальні засоби пластичних мистецтв - колір, форму, об'єм. I педагогічна, й образотворча діяльність мають емоційне забарвлення, яке $\epsilon$ важливим компонентом цих творчих процесів. Педагогічна діяльність здійснюється публічно, образотворча здебільшого індивідуально. Результати педагогічної діяльності динамічні, результатом образотворчої діяльності $\epsilon$ статичне зображення, а змінюватися може лише його сприйняття. 
Ураховуючи специфіку художньо-педагогічної діяльності вчителя образотворчого мистецтва, під професійною компетентністю ми розуміємо інтегроване професійно-особистісне утворення, в якому внутрішні ресурси людини, iї особисті якості й здібності розглядаються як джерело та критерії ефективної предметної діяльності в системі освіти. Ми схильні вважати, що це інтегративна властивість особистості, яка має комплекс професійно значущих для вчителя якостей, високий рівень науково-теоретичної, практичної підготовки до творчої художньо-педагогічної діяльності й ефективної взаємодії з учнями; впровадження сучасних технологій для досягнення високих результатів.

Висновки. Отже, за нашою позицією, професійна компетентність вчителя образотворчого мистецтва - це знання предмета, педагогіки, психології, принципів, форм і методів, технологій навчання і виховання, змісту предмета та індивідуальних особливостей учнів; володіння педагогічними технологіями; органічне поєднання теоретичної та практичної готовності до здійснення професійної художньо-педагогічної діяльності.

\section{Література}

1. Сухомлинський В. О. Вибрані твори: у 5-ти томах / В. О. Сухомлинський. - К. : Рад. школа, 1976-1977. - Т. 2. - С. 420-425; Т. 5. - С. 80-96.

2. Зимняя И. А. Ключевые компетенции - новая парадигма результата образования / И. А. Зимняя // Высшее образование сегодня. - 2003. - № 5. - С. 34-42.

3. Симонов П. В. Междисциплинарная концепция человека: потребностноинформационный подход / П. В. Симонов // Человек в системе нук. - М. : Наука, 1989. C. 58-73.

4. Чошанов М. П. Дидактическое конструирование технологии обучения / М. П. Чошанов // Педагогика. - 1997. - № 2. - С. 21-27.

5. Слободчиков В. И. Психологические основы личностно-ориентированного образования / В. И. Слободчиков // Мир образования - образование в мире. - 2001. - № 1. C. $14-28$.

6. Базаров Т. Ю. Век живи, век учись / Т. Ю. Базаров // Психологическая газета. 1999. - № 6. - С.12-13.

7. Философский словарь [Текст] / ред. М. М. Розенталь. - [3-е изд. ]. - М. : Политиздат, 1972. - 496 с.

8. Пасічний А. М. Образотворче мистецтво:[словник-довідник] / А. М. Пасічний. Тернопіль : Навчальна книга - Богдан, 2003. - 216 с.

9. Неменский Б. М. Мудрость красоты: О проблемах эстетического воспитания: [книга для учит.] /Б. М. Неменский. - [2-е изд., перераб. и доп. ]. - М. : Просвещение, 1987. -255 c.

10. Педагогика: [учеб. пособие для студ. пед. учеб. заведений] / В. А. Сластенин, И. Ф. Исаев, А. И. Мищенко, Е. Н. Шиянов. - [3-е изд. ]. - М.: Школа-Пресс, 2000. $512 \mathrm{c}$.

11. Власов В. Г. Новый энциклопедический словарь изобразительного искусства: В 10 т. / В. Г. Власов. - СПб. : Азбука-классика, 2004-2010. - Т. 4: И - К. - 2006. - 750 с.

Стаття надійшла до редакції 28.05.2012 р. 